\title{
Stratigraphic Commission Accelerates Progress, 1984 to 1989
}

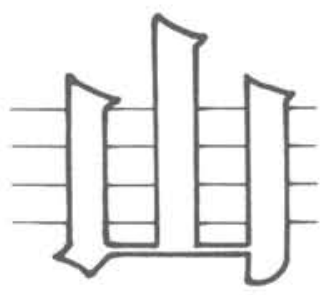

\section{by John W. Cowie, Willi Ziegler, and Jürgen Remane}

By far the largest of the constituent bodies of IUGS is the International Commission on Stratigraphy (ICS), which long predates the Union itself. In recent years it has concentrated on setting global standards for the stratigraphic column. This issue of Episodes encloses the first edition of the IUGS Global Stratigraphic Chart, which summarizes the progress to date. The number of new terms being proposed for Palaeozoic stages and for the Proterozoic is one measure of the close scrutiny that stratigraphers have given the rock column in recent years. The meticulous research that goes into this work is exemplified by the article in this issue by Chlupác and Oliver formally announcing the establishment of the Global Stratotype Section and Point for the Lochkovian-Pragian boundary of the Lower Devonian. The following review by several members of the overall Commission describes some recent newsworthy activities of the ICS. (Ed.)

\section{Introduction}

Stratigraphy gives a time scale and polarity (arrow) to organize the great body of geodata with a historical sense. With about 2,000 members organized in about 30 constituent bodies, ICS represents the global advancing front of stratigraphy - the core subject of the geological sciences. It organizes about 10 major and 20 minor conferences, workshops and "teach-ins" each year attended by groups of up to 500 persons. ICS activities can be considered under many headings and from diverse viewpoints.

\section{Subdividing the Proterozoic Eon}

The Subcommission on Precambrian Stratigraphy of ICS has recently voted in favour of the subdivision of $80 \mathrm{~g}$ of geological time as shown on Table 1 and in the Global Stratigraphic Chart enclosed in this issue of Episodes. The younger Proterozoic Eon has been divided into three eras and ten periods. This culmination of 20 years of progressive development is now being submitted to a postal ballot of Voting Members of ICS, and if a majority is in favour it will be submitted for ratification by the IUGS Executive Committee.

The Terminal Proterozoic System (Neoproterozoic III)

The aim of the recently established ICS Working Group on the terminal Proterozoic is to prepare an internationally acceptable set of recommendations for the establishment of the uppermost Proterozoic System. The primary task is to promote basic research that will increase our understanding of the biological, tectonic and environmental history recorded in upper Proterozoic rocks. System definitions and stratotype designations must be firmly rooted in such an understanding.

The late Proterozoic (Neoproterozoic) was a time of significant tectonic, biogeochemical, climatic and biological change. Consequently, several distinet sources of stratigraphically useful data are available. These include Metazoo and metazoan ichnofossils. Acritarchs and other microfossils are the most numerous fossils in all upper Proterozoic rocks, as well as in all Phanerozoic systems. The
TABLE 1: Proposed Subdivision of the Precambrian

Eon Era Period

(Base of Cambrian) "Neoproterozoic 世" $650 \mathrm{Ma}$

Neoproterozoic Cryogenian

$850 \mathrm{Ma}$

Tonian

Stenian

$1200 \mathrm{Ma}$

Ectasian

$1400 \mathrm{Ma}$

Calymmian

PROTEROZOIC

\begin{tabular}{cc}
\hline & \\
& \\
& Statherian \\
& $1800 \mathrm{Ma}$ \\
& Orosirian \\
& $2050 \mathrm{Ma}$ \\
Paleoproterozoic & Rhyacian \\
& $2300 \mathrm{Ma}$ \\
& Siderian \\
\hline
\end{tabular}

ARCHEAN

Greek Derivations of Period Terms (Supplied by Eric Welin)

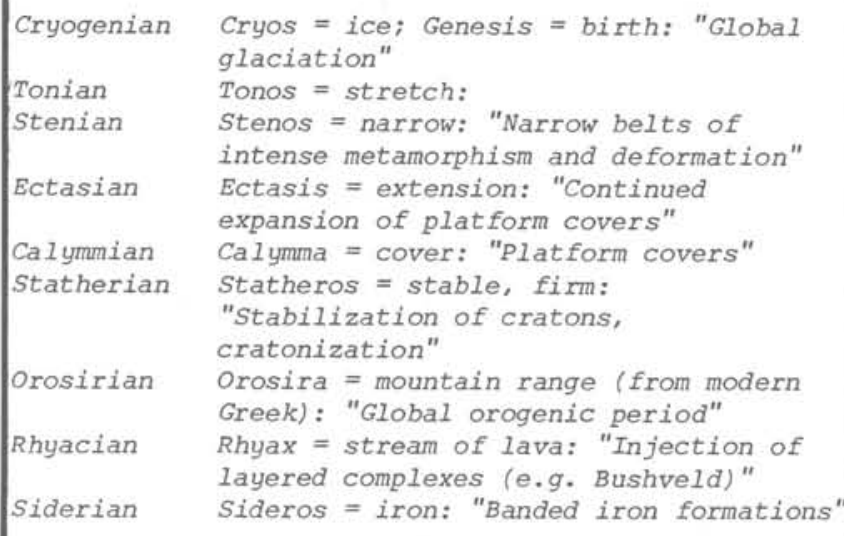


biostratigraphic potential of these assemblages is as yet incompletely realized. Metaphytes - seaweeds from a variety of upper Proterozoic localities also appear to be useful biostratigraphic markers, as do stromatolites and micro-phytolites both in terms of lithostratigraphy and biostratigraphy.

Rapidly improving data on secular variation in stable carbon, sulphur, strontium, and neodymium isotopic ratios in upper Proterozoic carbonates, kerogen, phosphorites, and sulphates suggest that isotopic chemostratigraphy may be particularly useful in eorrelating upper Proterozoic sedimentary successions. As regards palaeomagnetics, both reversal stratigraphy and apparent polar wander paths have the potential to refine upper Proterozoic correlations.

The sedimentary petrology and geochemistry of upper Proterozoic sediments may contribute to their correlation. Potentially useful features might include the presence or absence of micro-bioturbation, the presence or absence of fecal pellets, and the mineralogy and geochemistry of ooids. Sequence and event stratigraphy has the potential to increase our understanding of sea-level change, climatic oscillations and regional tectonic events. Glaciogenic rocks, in particular, have a strong potential for correlation.

The Precambrian-Cambrian Boundary

Since the Moscow Geological Congress in 1984, research under ICS, has been expanded and intensified in many subject areas in many parts of the world. IGCP Project 29, which was active from 1974 to 1987 (Cowie and Brasier, 1989), also made extensive contributions to this knowledge. It still remains to differentiate and identify fully the assemblage of "small shelly fossils" that is uniquely earliest Cambrian in age. Because it is agreed that the delineation and guidance for the Precambrian-Cambrian Boundary is primarily biostratigraphic, this work is vitally important.

Small shelly fossils, critical in zoning the PrecambrianCambrian boundary interval, particularly in the carbonate facies of Central Asia, cause taxonomic problems because of their morphologic variability and multi-element nature. The Tethyan carbonates of Asia (including Meischucun) show several potential horizons for correlation (Fig. 1). Research is proceeding apace on "Tethyan" boundary correlation on the phosphogenic belt that stretches from the Yangtze Platform in China, through the Lesser Himalaya of India and

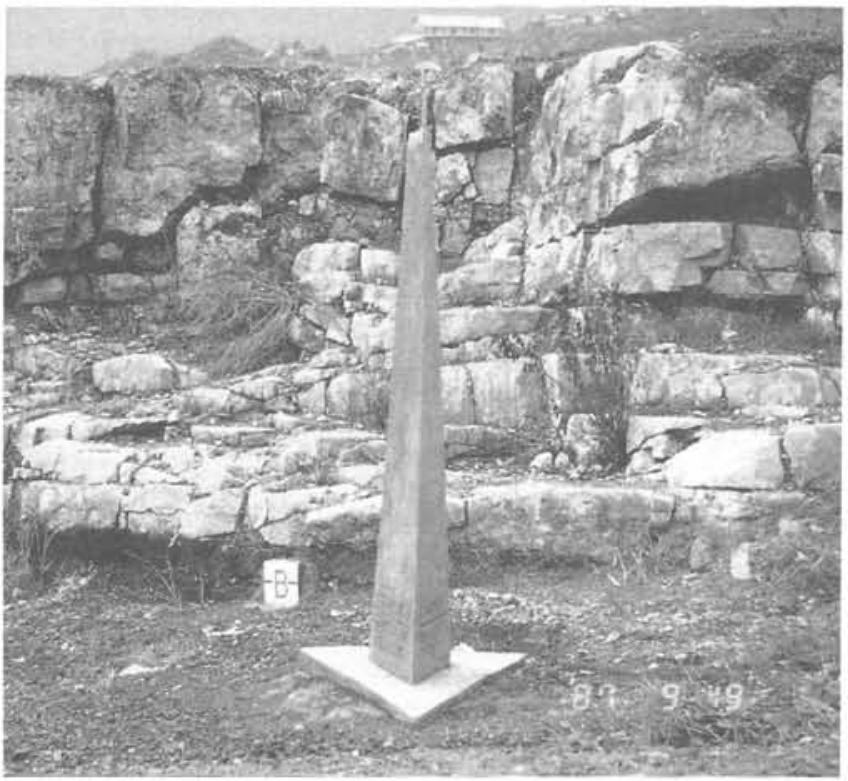

Figure 1: The marker at the Precambrian-Cambrian boundary at Meischucun (Kunyang Phosphate Quarry). Jinning County, Yunnan, China. A GSSP candidate.

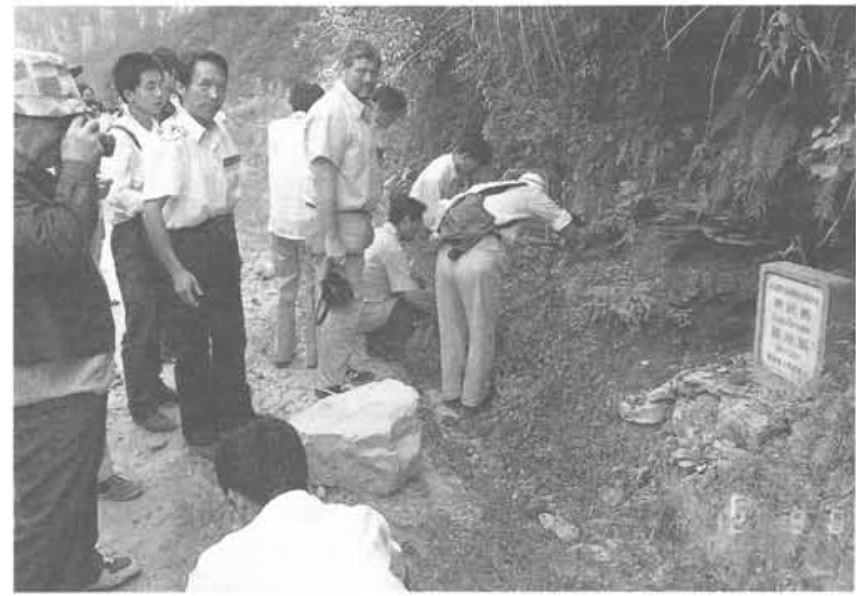

Figure 2: Studying the Sinian-Cambrian boundary in the Yangtze Gorge region near Yichang, Hubei, China.

northern Pakistan, to the Alburz Mountains in Iran. Similar lithological and microfossil successions in this belt suggest that they were adjacent blocks on the northern margin of early Gondwanaland.

Inter-continental correlation of small shelly fossils remains controversial, with several distinct correlations of the main three candidate stratotypes (East Siberia, China and Canada). Trace fossils are especially common in siliciclastic facies, in which shelly fossils typically are rare and poorly preserved. Correlation in siliciclastic facies is critical, as these deposits comprise nearly $70 \%$ of exposed rocks in the boundary interval. However, careful morphologic analysis, rigorous taxonomy and detailed documentation of the stratigraphic ranges of ichnotaxa are proceeding on more sections, particularly in Australia and the Russian Platform, to further test the correlations.

The Subcommission on Precambrian Stratigraphy has agreed that the main subdivision of Precambrian rocks should be based on geochronometry and that this Precambrian geochronometric time scale must, if possible, be correlated with the chronostratigraphic time scale by good isotope dating for the beginning of the Palaeozoic Era (the beginning of the Cambrian Period). Chronostratigraphy is the classificatory and defining factor for the Cambrian and later periods and also for the Precambrian-Cambrian Boundary (Fig. 2).

A new result is the date of $565 \pm 3 \mathrm{Ma}$ (U-Pb in zircons) for an ash bed at Mistaken Point in eastern Newfoundland, Canada, containing soft-bodied metazoans. The regional stratigraphic position of this bed relies on lithostratigraphic correlation and is, however, more than $7000 \mathrm{~m}$ below the putative Precambrian-Cambrian boundary horizon. The age of the Precambrian-Cambrian Boundary calibrated in millions of years has a wide range of uncertainty but may be more accurately known in the next decade or so. In the meantime an age of $? 570 \mathrm{Ma}$ may not be too far from the truth. There is an urgent need for new reliable dates with a global spread of localities. It is obviously most important that the Precambrian-Cambrian GSSP should have numerous accurate isotopic dates available to the highest modern standards.

Although magnetostratigraphy is a secondary method, relying on biostratigraphy and geochronometry for primary generalized placing of its data in the geological time scale, it is probably going to contribute much to the "fine-tuning" of international correlation of the Precambrian-Cambrian Boundary. This has already been achieved between the well-documented and correlated sections of the Aldan and Lena River sections in Yakutia, U.S.S.R. (Fig. 3), and Chinese outcrops are also being studied. 
The situation as regards accessibility and conservation (see Cowie, et al., 1986) in 1989 for Precambrian-Cambrian GSSP candidates is as follows. For Meischucun there has been no change from 1984, apart from road access improvements and fencing off of the section with complete "national monument" conservation assured by the national and local government agencies. For Fortune, Burin Peninsula, Newfoundland, the section is in danger due to the dumping of garbage. Protective measures are, however, being negotiated. For Ulakhan-Sulugur, Yakutia, (east Siberia, U.S.S.R.), there seems to be a substantial improvement in access to the Tommotian-Yudomian sections. Access to Yakutsk by air is now quite easy and used by tourists, with helicopters available by charter. The new branch of the Siberian railway passes through Tommot, and there is a station there now. Boat travel on the Aldan is extensive, and there is a newly improved road from Yakutsk to Tommot.

\section{Devonian Series and Stage Boundaries}

From the start of its work in 1973 the Subcommission on Devonian Stratigraphy (SDS) concentrated on refining and redefining series and stage boundaries.

The Lower/Middle Devonian Boundary was the first to be established in 1982 by defining the boundary level through the first occurrence of the conodont $P$. costatus partitus and the GSSP (Global Stratotype Section and Point) at the level $20.80 \mathrm{~m}$ in the stratotype section at the Wetteldorf Richtschnitt, Eifel Hills, West Germany. By this definition, which was formally adopted by ICS and the IUGS Executive Committee in 1982, the lower limit of the Eifelian, the first stage within the Middle Devonian Series, was established to coincide with the Lower/Middle Devonian Series Boundary at the same time. This limit has been successfully traced globally (Ziegler, 1986).

In 1982 the Middle/Upper Devonian boundary level had been guided by the first appearance of the conodont Ancyrodella rotundiloba (Ziegler and Klapper, 1985), which is coincident with the lower boundary of the Lower asymmetricus Zone in the conodont standard zonation. The GSSP was marked by SDS in a section in the Montagne Noire, Col du Puech de la Suque, at the base of bed $42 \mathrm{a}$ (Klapper et al., 1987; see also Sandberg, Ziegler and Bultynck 1988; Klapper 1988, and Sandberg, Ziegler and Bultynck, 1989).

As regards the Devonian stage boundaries, SDS decided in 1983 that the classic Lower Devonian areas (Gedinnian, Siegenian and Emsian) were not suitable for revision of stratigraphic boundaries and for correlation on a global

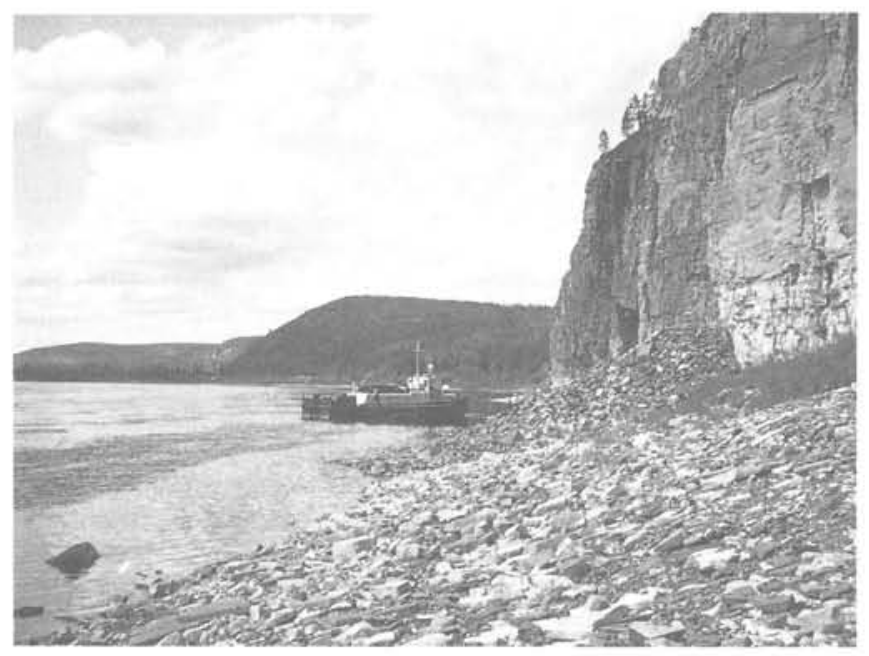

Figure 3: The Aldan River section at UlakhanSulugur, Yakutia, eastern Siberia, U.S.S.R. Another global candidate for the Precambrian-Cambrian stratotype. scale. SDS, however, agreed upon the nomenclature of the Lower Devonian stages Lochkovian, Pragian and Emsian. As the lower limit of the Lochkovian Stage was established in 1972 by the Silurian-Devonian Working Group at the system's lower boundary in the stratotype at Klonk, CSSR, the focus for Lower Devonian stages has been on the Pragian and Emsian.

Discussion of the Lower Pragian Boundary has taken into consideration many areas (e.g. Middle Asia, North Africa, western U.S.A., Central Europe, Spain) where Lower Devonian rocks are exposed. In 1987, the Barrandian area (Czechoslovakia) and Nevada (U.S.A.) were nominated the best candidates for the Lower Pragian Boundary, and in 1988 during the Rennes Meeting a proposal was submitted by Chlupac, Luces and Weddige, favouring a stratigraphic level coincident with the first occurrence of the conodont Eognathodus sulcatus, and a GSSP at the stratotype section at Velká Chuchle in the Barrandian area at the base of bed 12 marked in the quarry section (see Chlupáč and Oliver, this issue - Ed.).

The new boundary is slightly beneath the former (megafossil) boundary of local usage. In addition to the conodont development, the tentaculite and palynomorph successions are well documented, and other fossils are abundant and well known. This boundary is thus correlatable throughout the world, and it was accepted by SDS unanimously. The decision by ICS and IUGS was completed in 1989, and the GSSP is now ratified.

Both a defining level and a GSSP for the Lower Famennian Stage Boundary were selected in 1987 , but both were rejected in the mail ballot because of questions subsequently raised about the stratotype section. In 1988, the selection of the defining level, as made a year before, was reaffirmed. However, it was decided that a section in Moroceo might potentially be better than those previously considered and that it should be further studied as a possible GSSP.

A formal motion reaffirming the boundary level at the base of the Lower triangularis Zone of the conodont standard zonation was passed unanimously. It was subsequently the subject of a mail vote of the membership. The result of this ballot was "yes" by an $80 \%$ majority.

The hitherto proposed stratotype sections were rejected. In a formal submission a potential stratotype at El Atrous, Moroceo, was proposed for further studies with the expectation that it could be proposed as the GSSP in 1989.

Discussions on the Lower Emsian Stage Boundary in 1988 concentrated, as in years before, on the first appearance of Polygnathus dehiscens as a level for the Lower Emsian boundary. SDS is eager to make progress on the base of the Emsian, and it invites statements on sequences within the overlap of Polygnathus pyreneae and P. dehiscens or at other appropriate levels. It also desires information on the range of taxa other than conodonts that are close to the boundary. Teams in Asia, Middle Asia (U.S.S.R.) and in China are now assembling data from their sections. It is hoped that proposals will be submitted in 1989 or 1990.

\section{Devonian-Carboniferous Boundary}

Following an agreement on a boundary level (i.e. first occurrence of Siphonodella sulcata and its coincidence with lower limits of Dinantian, Tournaisian, Mississippian, Kinderhookian, and other chronostratigraphic units as early as 1979 (Paproth and Streel, 1985), the Working Group has been in search of an appropriate boundary stratotype.

During this search many countries have been visited, but it has proved difficult to find a section that represents the conodont succession Siphonodella praesulcata - S. sulcata satisfactorily. The search had been made difficult by realization that a brief eustatic fall in sea level just before 
the end of the Devonian resulted, even in the best candidate section of the mid-1980s, in a short stratigraphic interval in which the pelagic siphonodellid biofacies is interrupted by a more nearshore protognathodid biofacies. Siphonodella praesulcata of the siphonodellid succession is very scarce. The lowering of sea level is manifested by mass extinction of Devonian fossils including many conodonts, and by abrupt lithologic changes like regressive and turbiditic sandstones, hardground, unconformities, and knife-edge contacts between beds (Ziegler and Sandberg, 1984).

However, in 1987 and 1988, world-wide activities had brought forth several sections that produced a seemingly uninterrupted succession with the S. praesulcata - S. sulcata lineage. Among those were pelagic sections at Drewer (Rhenish Mountains), Dapoushang (Guizhou, China), Nanbiancun (near Guilin, Guangxi, China; Ziegler et al., 1988), Grüne Schneid (Austrian Alps; Schönlaub et al., 1988), and La Serre, Montagne Noire (Flajs and Feist, 1988).

The Working Group, in May 1988, rejected all proposed sections except the La Serre section because of the belief that Drewer, Dapoushang and Grüne Schneid had yielded only incomplete information regarding fossil content of the critical interval. The Working Group also favoured La Serre because it is the only one that contains a continuous sucession of conodont assemblages exhibiting a gradual passage from Siphonodella praesulcata to Siphonodella sulcata" (Working Group submission to ICS and IUGS, January 1989, p. 8). This statement probably needs correction to the extent that the Drewer, Dapoushang, and most likely also the Nanbiancun sections have a definitely uninterrupted sequence from $\mathrm{S}$. praesulcata into $\mathrm{S}$. sulcata.

Three conodont specialists and members of the Working Group (C.A. Sandberg (U.S.A.), Wang Chen-yuan (China), and W. Ziegler) have doubted the unbroken quality of the sequence of the La Serre section (in a postal circular letter to the members of the Working Group in August 4, 1988), because of heavy reworking and of probable earlier occurrence in the section of S. sulcata (possibly at bed 85 ). If this is the case, then the whole sequence containing the supposed praesulcata-sulcata lineage is an artefact created by reworked sediments derived from different source areas within the sulcata zone and above the D/C Boundary position. The latter would thus be at the base of bed 85 (abrupt change in sedimentology) rather than at bed 89 as selected by the Working Group.

Sandberg, Wang and Ziegler believe that there are several misidentifications in the material of Flajs and Feist (1988), which has been in the repository of the Senckenberg Museum since late July 1988. They, therefore, doubt the wisdom of proposing a phylogenetic sequence based upon a few indigenous conodonts with almost totally reworked faunas. The

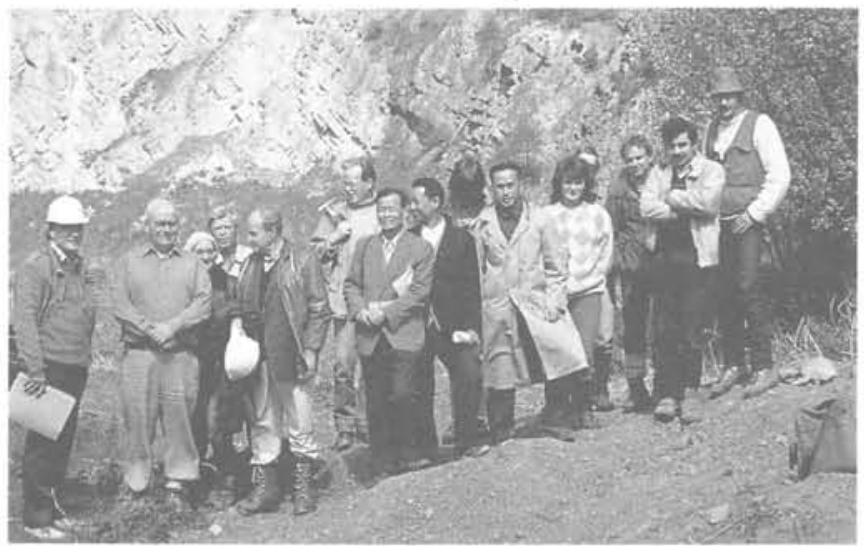

Figure 4: The ICS Working Group on the PrecambrianCambrian Boundary in front of a quarry face exposing the Lower Cambrian Wrekin Quartzite near Telford, Salop, England.
Working Group now seeks acceptance and ratification of a GSSP at the base of Bed 89 at La Serre on the basis of a $70 \%$ majority vote of the voting members.

\section{Subsystems of the Carboniferous}

There have been long delays in reaching a decision about whether or not, on a global geochronological scale, the Carboniferous should be divided into two or three parts Extensive discussions at the XIth International Congress of Carboniferous Stratigraphy and Geology (Beijing, 1987) finally led to a solution. There the Carboniferous Subcommission had the opportunity to integrate new results and proposals from a large international assembly of specialists.

The postal ballot organized the following year among voting members of the SC confirmed the decisions taken at Beijing. These were that the Carboniferous shall be a single system, subdivided into two subsystems. The Mid-Carboniferous boundary working group is now seeking a potential stratotype section, and further subdivision of the two subsystems will be pursued by two interregional working groups established at Beijing.

In addition, the International Working Group on the Carboniferous-Permian boundary was reestablished and is now actively pursuing its task under the chairmanship of Wu Wang-Shi of the Nanjing Institute of Geology and Palaeontology.

\section{Cretaceous-Palaeogene Boundary}

After many years of studies, the C-P (K-T) Boundary Working Group seems to have arrived at an advanced stage in choosing the GSSP. In 1982, by a large majority decision the Working Group voted to include the Danian into the Tertiary. The selection of an actual boundary stratotype, however, was delayed until 1987, when it was decided to look in detail at four C-P sections as a possible GSSP: a Brazos River section (U.S.A.), El Kef (Tunisia), Stevna Klint (Denmark), and Zumaya (Spain). None of these is ideal but El Kef seems to be the most complete, although it lacks magnetostratigraphy and macrofossils; the Brazos section has a tsunamite at the boundary beds; Stevna Klint is boreal and, therefore, more difficult to correlate; and Zumaya is slightly tectonized at the boundary.

By ballot in November 1988, the WG membership was asked to vote for one of the above localities (with the freedom to vote for others) and for a boundary level at the Base of the Tsunamite, the Base of Boundary Clay, the First occurrence of Dinoflagellata Danea california, the Ir-Maximum in the Boundary Clay or another position. Of the votes cast for the locality, ten $(48 \%)$ voted for Kef, two for Brazos, two for Stevns, six for Zumaya, and one for another. According to the ICS guidelines, a $60 \%$ majority is needed for acceptance. Concerning the boundary level, $64 \%$ voted for the base of the Boundary Clay as the GSSP.

In a subsequent and final ballot, a $75 \mathrm{o}$ majority of Voting Members voted for the Base of the Boundary Clay at El Kef to be the GSSP, thus combining in one vote stratigraphic level and geographical location. Submission of this decision to a vote of the Voting Members of ICS will take place soon, followed, if successful, by a request for ratification by the IUGS Executive.

Cooperation is under way between ICS and the newly established IUGS Commission on Global Sedimentary Geology. In a general way, this is a matter of correlating global events, recognizable more or less worldwide in the sedimentary record, to the standard stratigraphic scale. Once calibrated, such events will become a powerful tool for correlation, especially for the Mesozoic. Thus, the famous K-T event is a powerful additional tool for correlating the Cretaceous-Palaeogene boundary. Type sections under discussion as candidates for a GSSP were preferably chosen to show a sedimentary documentation of the boundary event (e.g. boundary clay Ir anomaly). 